10.2478/aucft-2019-0013

\title{
EFFECT OF CARBON SOURCES, NITROGEN SOURCES AND PREBIOTICS ON GROWTH OF SACCHAROMYCES BOULARDII
}

\author{
- Research paper -
}

\author{
Xin Yang ${ }^{*}$, Guowei Shu*, Zhangteng Lei*, Guanli Du**, Zemin Liu ${ }^{* *}, \mathrm{Jili} \mathrm{Cao}^{1 * * *}$ \\ * School of Food and Biological Engineering, Shaanxi University of Science and Technology, Xi', \\ 710021, China; **Department of Research and Development, Xi'an Xiyangyang Biological \\ Technology Co., Ltd., Xi'an, China; ***Xi'an Oriental Dairy Co., Ltd., \\ Xi'an, Shaanxi 710027, China
}

\begin{abstract}
Saccharomyces boulardii ( $S$. boulardii) has been used as a probiotic for the prevention or treatment of various human gastrointestinal diseases for many years. Thus, $S$. boulardii has a wide range of application prospects in medicine and food industry. The experiments were investigated with effecting of carbon sources (galactose, sucrose, fructose, maltose, lactose, glucose, and soluble starch), nitrogen sources (tryptone, casein, yeast extract, peptone, soy peptone, beef extract and malted milk; ammonium sulfate, urea, diammonium hydrogen citrate, triammonium citrate, ammonium nitrate, ammonium chloride and potassium nitrate), prebiotics (xylo-oligosaccharide, isomaltooligosaccharide, fructo-oligosaccharide, galacto-oligosaccharide, stachyose, raffinose and inulin) on the number of viable cells and dry cell weight of $S$. boulardii. The optimum concentration of $5 \%$ glucose or sucrose, $2 \%$ peptone or yeast extract, $0.4 \%$ urea, $0.2 \%$ fructo-oligosaccharide and $0.6 \%$ galacto-oligosaccharide for $S$. boulardii grew better in medium.
\end{abstract}

Keywords: Saccharomyces boulardii; carbon source; nitrogen source; prebiotics

\section{INTRODUCTION}

At present, consumers have been seeking for bioactive or functional foods that supply additional health benefits (Kailasapathy, 2015). Probiotics are modern phrases, meaning "life", and used to name bacteria that are good for human and animal health (George Kerry et al., 2018). It improves the balance of intestinal micro-ecology in the host (animal or human) (McGroarty, 1993), enhance human immunity and promote the absorption of nutrients (Perdigon et al., 1995). In addition, probiotics also have physiological functions, which contribute to regulate the health of the host environment of microbes and help to control overweight and obesity. The main carrier of probiotic foods is dairy products, but they can also be found in other kinds of foods (CoronaHernandez et al., 2013).

Most probiotics are bacteria, but Saccharomyces boulardii as a yeast, has been found to be an effective probiotic in studies (Czerucka et al., 2010). $S$. boulardii is considered to be a known

Received: 29.10.2019.

Accepted in revised form: 6.12 .2019
GRAS (Generally Recognized As Safe) microorganism that has probiotic activity to microbial pathogens in the intestinal lumen (Ghasem et al., 2018). In 1923, French scientist Henri Boulardii isolated $S$. boulardii from litchi fruit in Indonesia (McFarland, 2010), which has many specific properties. The optimal growth temperature is $37^{\circ} \mathrm{C}$ (physiological temperature of the host), both in vitro and vivo (Jean-Paul et al., 2001; Edwards-Ingram et al., 2007), and the yeast is resistant to acidity. S.boulardii possesses a variety of properties, making it a potential probiotic agent, and can inhibit the growth of some pathogenic microorganisms (Fietto et al., 2004; Malgoire et al., 2005).

The effects of probiotic yeast $S$. boulardii as a biotherapeutic agent are well known. In many countries, this yeast is processed into lyophilized product for the treatment of diarrhea in children and adults. Pharmacokinetic (Elmer et al., 2000) studies showed that after continuous oral, $S$. boulardii could be appear in the colon stability about 3 days. It will be excreted in the feces rather than colonized in the intestine when the drug has stopped. The fungal preparation of $S$. boulardii is not degraded by antibiotics, can be used not only

\footnotetext{
${ }^{1}$ Corresponding author. E-Mail address: xiandfcj1@gmail.com
} 
with antibiotics but also effectively prevent the use of antibiotics with dysbacteriosis (Akil et al., 2006). S. boulardii is widely used to prevent and treat diarrhoea associated with among others use of antibiotics, Vibrio cholerae or Clostridium difficile infection, gastroenteritis and irritable bowel syndrome (Vanhee et al., 2010). This yeast remains viable in the gastrointestinal tract and inhibits the growth of pathogenic bacteria (Szajewska and Mrukowicz, 2005; Szajewska et al., 2007; Mansour-Ghanaei et al., 2003; McFarland. 2006). The efficacy of $S$. boulardii against antibiotic-associated diarrhea in humans has been demonstrated in double-blind-controlled trials.

As probiotic, $S$. boulardii has to reach a sufficient number of viable cells in order to ensure the biological effects. However, there are scarce reports involved in the medium composition of $S$. boulardii. To achieve the probiotic benefits, selected live yeast cells need to reach the sufficient amount of cell. Therefore, the effects of three sources (carbon sources, nitrogen sources, and prebiotics) on the growth of S.boulardii were investigated in this study, which provided insights for further optimization of $S$. boulardii medium.

\section{MATERIALS AND METHODS}

\section{Microorganism}

The probiotic strains employed in the present study was Saccharomyches boulardii, which were provided by School of Food and Biological Engineering, Shaanxi University of Science \& Technology. All chemicals used were of analytical grade.

\section{Cultivation conditions}

S. boulardii was grown and activated in Yeast Extract Peptone Dextrose Medium (YPD) containing $10 \mathrm{~g}$ peptone, $10 \mathrm{~g}$ yeast powder, $20 \mathrm{~g}$ glucose, then dissolved in $1000 \mathrm{~mL}$ distilled water and autoclaved at $121{ }^{\circ} \mathrm{C}$ for $15 \mathrm{~min}$. S. boulardii was inoculated in $35 \mathrm{~mL} / 250 \mathrm{~mL}$ of medium at a level of $2 \%(\mathrm{v} / \mathrm{v})$, and incubated at $37^{\circ} \mathrm{C}$ for $36 \mathrm{~h}$ in the shaker at $180 \mathrm{rpm}$. It was confirmed by microscopy that there were no miscellaneous bacteria in the medium, and then activated three successive times and incubated under the same conditions. The activation and inoculation was operated on the super clean workable.

\section{Determination of viable counts}

The viable counts of $S$. boulardii was determined by plate counting method. The sample was diluted
10 times in sequence to the proper gradient. After that, $0.1 \mathrm{~mL}$ of solution was injected into the YPD agar plate and coated uniformly. The plates were incubated at $37{ }^{\circ} \mathrm{C}$ for $48 \mathrm{~h}$. Each sample does two dilution degrees. Selected the number of colonies between 30 and 300, and then calculated the number of viable cells $(\mathrm{CFU} / \mathrm{mL})$.

\section{Determination of dry weight}

The $30 \mathrm{~mL}$ bacterial suspension was taken in a centrifuge tube (precipitated in a centrifuge tube). The supernatant was discarded and collected the cells after centrifugation for $10 \mathrm{~min}$ at $6000 \mathrm{r} / \mathrm{min}$. The collected cells were dried in a dry box at 105 ${ }^{\circ} \mathrm{C}$ to a constant weight, then weighed and calculated the dry weight of the bacteria $(\mathrm{g} / \mathrm{L})$.

\section{Determination of $\mathbf{p H}$}

The $\mathrm{pH}$ of the solution was measured triplicate directly at room temperature using a $\mathrm{pH}$ meter.

\section{Data analysis}

The Origin 9 software package (Origin Lab Inc., Alexandria, VA, USA) was used to show the viable counts and the dry cell weight of $S$. boulardii.

\section{RESULTS AND DISCUSSION}

\section{Effect of carbon sources on the growth of Saccharomyces boulardii}

In this experiment, $2 \%$ glucose, fructose, sucrose, maltose, lactose, galactose, and soluble starch were used as the sole carbon source by changing the carbon source of YPD medium. YPD medium without glucose was used as the control group. After sterilization and cooling, $3.1 \%$ of $S$. boulardii was separately added. The liquid loading was $52 \mathrm{~mL} / 250 \mathrm{~mL}$ and the initial $\mathrm{pH}$ value of medium was adjusted to 6.4 . The medium was cultured at $37^{\circ} \mathrm{C}$ for $24 \mathrm{~h}$ at $180 \mathrm{r} / \mathrm{min}$. 
Glucose, sucrose, and maltose promote the growth of the $S$. boulardii, in which glucose and sucrose were more effective (Figure 1).

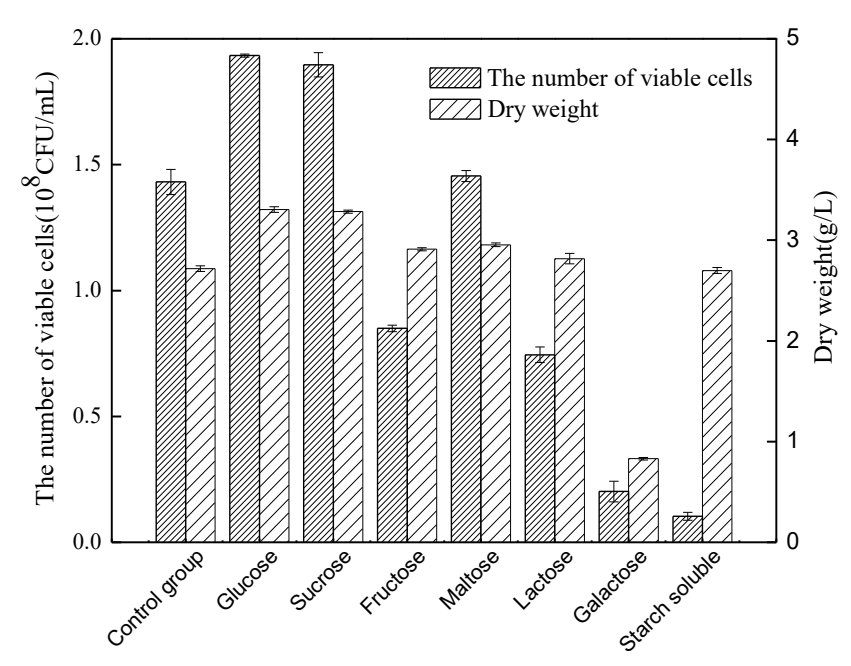

Figure 1. Effect of carbon sources on the growth $S$. boulardii

However, fructose, lactose, galactose, and soluble starch were not conducive to the growth of $S$. boulardii. When the carbon source was glucose, the number of viable cells was $1.93 \times 10^{8} \mathrm{CFU} / \mathrm{mL}$ and the dry cell weight was $3.3033 \mathrm{~g} / \mathrm{L}$. When sucrose was the sole carbon source, the viable counts and the dry cell weight were $1.89 \times 10^{8}$ $\mathrm{CFU} / \mathrm{mL}$ and $3.2833 \mathrm{~g} / \mathrm{L}$, respectively. Therefore, subsequent tests selected glucose and sucrose as carbon sources.

As the concentration of glucose increased, it was beneficial to the growth of the cell, the number of viable cells and the dry cell weight began to increase significantly (Figure 2a). When the concentration of glucose was $5 \%$, the number of viable cells was $2.41 \times 10^{8} \mathrm{CFU} / \mathrm{mL}$ and dry cell weight was $5.9556 \mathrm{~g} / \mathrm{L}$. Figure 2(b) indicated that as the concentration of sucrose increased, the number of viable cells and dry cell weight gradually increased. When the concentration of sucrose was $5 \%$, the viable counts and dry cell weight reached $2.33 \times 10^{8} \mathrm{CFU} / \mathrm{mL}$ and $5.8123 \mathrm{~g} / \mathrm{L}$, respectively. In addition, Figure 2 exhibited that the $\mathrm{pH}$ of the culture solution began to decrease as the concentration of glucose and sucrose increased, which may be caused by acid production during the growth and metabolism of the cell.

The carbon source is an important source of energy for yeast growth, a sufficient carbon source is beneficial to the growth of the cells. In the process of yeast growth and metabolism, the carbon source mainly provides carbon skeletons for cells and synthetic products, and can provide the energy required for cell life activities. Anvari et al. showed that lactose concentration of $9 \cdot 5 \mathrm{~g} / \mathrm{L}$; inulin concentration of $38.5 \mathrm{mg} / \mathrm{L}$; yeast extract concentration of $9 \cdot 6 \mathrm{~g} / \mathrm{L}$ and initial $\mathrm{pH}$ of 6.2 were the optimal conditions for the growth of Bifidobacterium animalis subsp. lactis PTCC 1736 (Anvari et al., 2013). According to Prabhu et al., gluconate and glycine were found to be key carbon and nitrogen sources, which had a significant effect on the production of human interferon gamma (hIFN- $\gamma$ ) in Pichia pastoris (GS115). The results showed that when the yield of hIFN- $\gamma$ was $30.99 \mathrm{mg} / \mathrm{L}$, the optimal concentration was gluconic acid of $50 \mathrm{~g} / \mathrm{L}$, glycine of $10.185 \mathrm{~g} / \mathrm{L}$, $\mathrm{KH}_{2} \mathrm{PO}_{4}$ of $35.912 \mathrm{~g} / \mathrm{L}$, and histidine of $0.264 \mathrm{~g} / \mathrm{L}$ (Prabhu et al., 2017).

\section{Effect of nitrogen source on the growth of Saccharomyces boulardii}

\section{Effect of organic nitrogen source on the growth of Saccharomyces boulardii}

Tests with $1 \%$ yeast extract, peptone, soy peptone, tryptone, casein peptone, beef extract and malted milk added to the YPD medium without nitrogen source, the YPD medium without nitrogen source was used as the control group. The effect of organic nitrogen sources on cell growth is shown in Figure 3. After the addition of different nitrogen sources, the number of viable cells and the dry cell weight increased significantly, compared with the control group. The effects of different nitrogen sources on the growth of $S$. boulardii were different. The order of utilization rate of different nitrogen sources was: yeast extract $>$ peptone $>$ beef extract $>$ malted milk $>$ tryptone $>$ peptone $>$ casein peptone, in which yeast extract and peptone significantly promoted the growth of $S$. boulardii, and the viable counts of yeast extract group and peptone group were $1.45 \times 10^{8} \mathrm{CFU} / \mathrm{mL}$ and $1.36 \times 10^{8} \mathrm{CFU} / \mathrm{mL}$, respectively. The dry cell weights were $2.5066 \mathrm{~g} / \mathrm{L}$ and $2.4244 \mathrm{~g} / \mathrm{L}$, respectively.

Yeast extract is rich in nutrients such as protein, amino acids, vitamins and trace elements, which can promote the growth of $S$. boulardii; peptone contains not only organic nitrogen compounds but also some vitamins, sugars and growth factors. And is also suitable for the growth of $S$. boulardii. So choose peptone and yeast extract for the next experiment. 


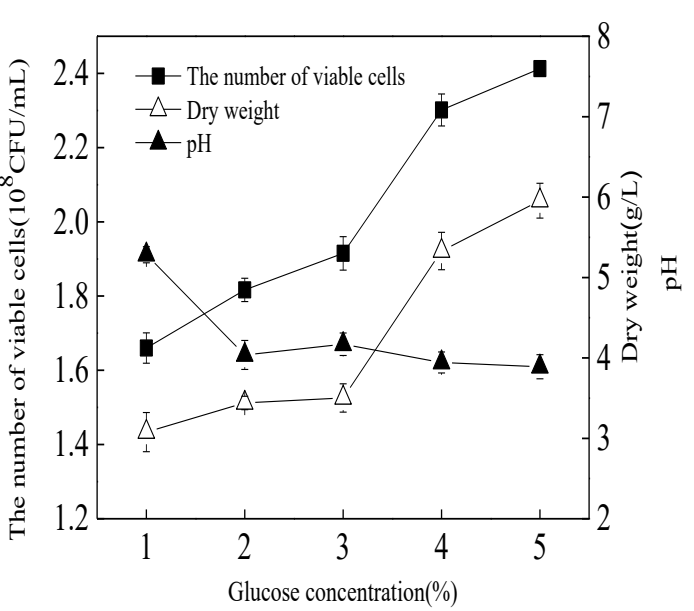

(a)

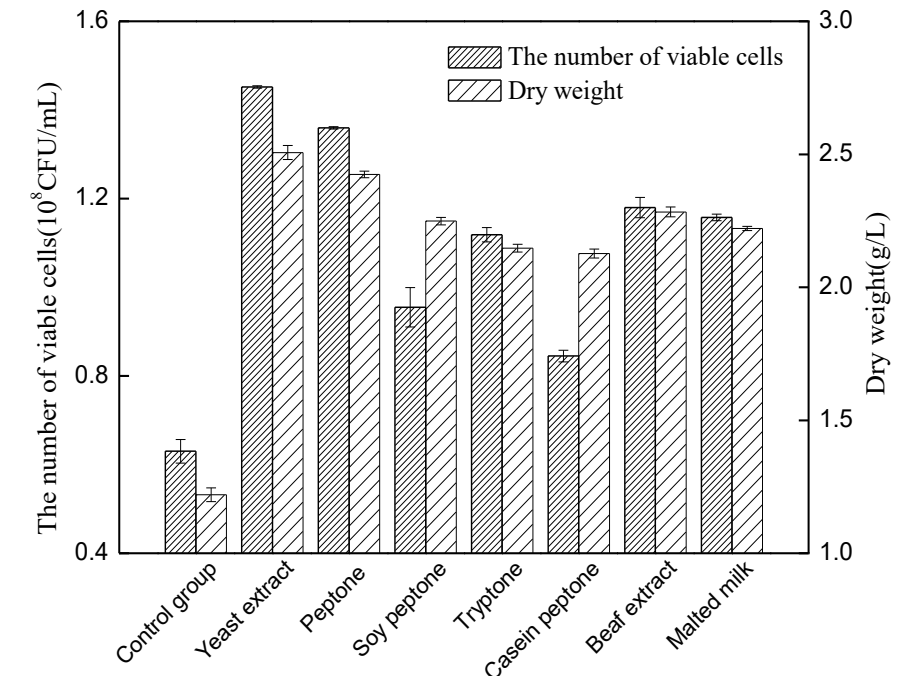

Figure 3. Effect of organic nitrogen sources on the growth of S. boulardii

With the increase of yeast extract and peptone concentration, the number of viable counts and the dry cell weight increased and then decreased

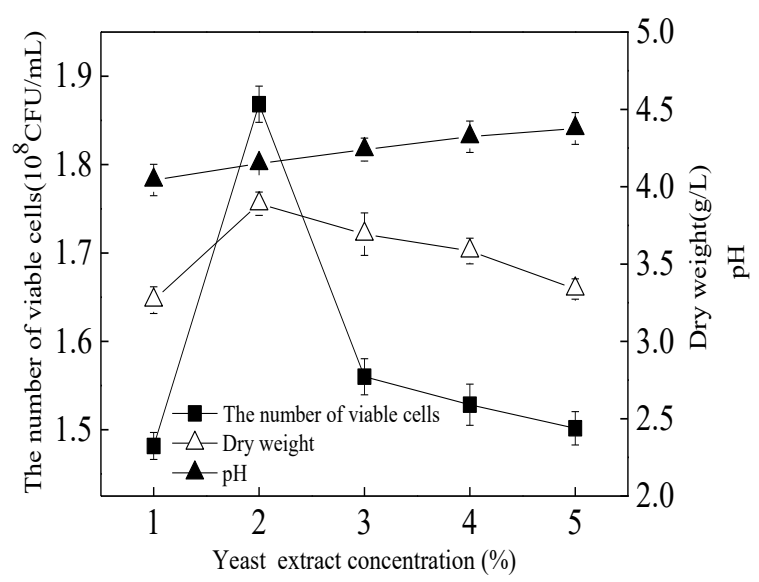

(a)

Figure 4. Effect of the concentration of yeast extract (a) and peptone (b) on the growth of S. boulardii

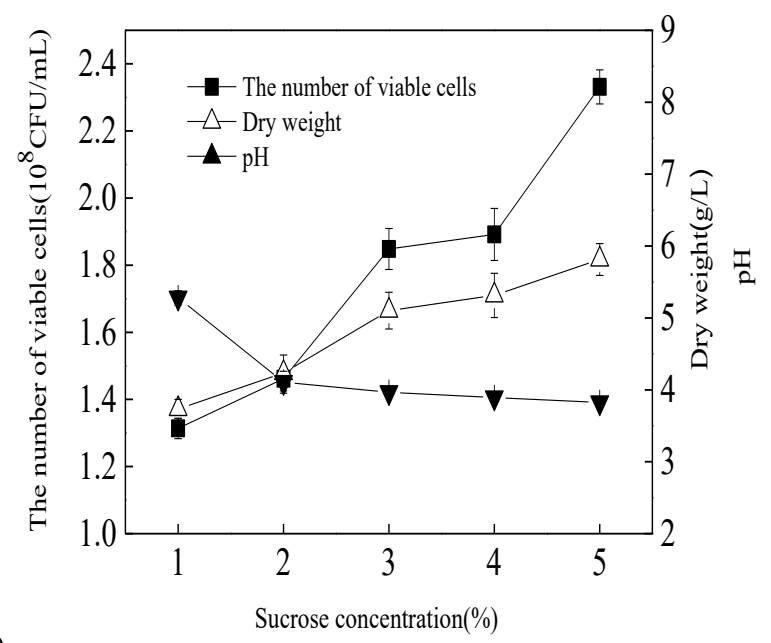

(b)

(Figure 4). When the concentration of yeast extract and peptone was $2 \%$, the maximum number of viable counts were $1.87 \times 10^{8} \mathrm{CFU} / \mathrm{mL}$ and $1.85 \times 10^{8} \mathrm{CFU} / \mathrm{mL}$, respectively, the dry cell weight was $3.8926 \mathrm{~g} / \mathrm{L}$ and $3.8345 \mathrm{~g} / \mathrm{L}$. Furthermore, the $\mathrm{pH}$ value of culture solution increased with the concentration of the yeast extract increased, but increased first and then decreased with the concentration of the peptone increased. According to the above results, $2 \%$ of peptone and yeast extract were beneficial to $S$. boulardii.

Effect of inorganic nitrogen source on the growth of Saccharomyces boulardii

$0.5 \%$ ammonium sulfate, urea, diammonium hydrogen citrate, triammonium citrate, ammonium nitrate, ammonium chloride, and potassium nitrate were added to the YPD medium. The effects of different inorganic nitrogen sources on the growth of $S$. boulardii were compared with YPD medium as control group.

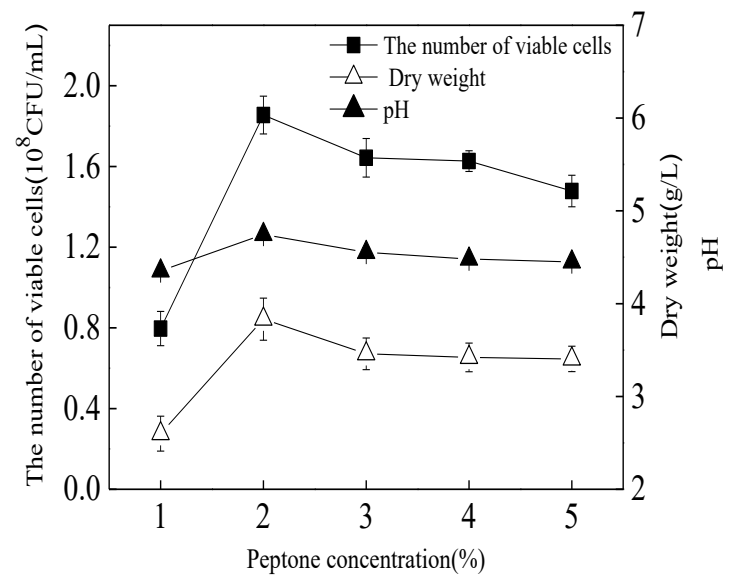

(b) 
As Figure 5 shows, after adding the above seven inorganic nitrogen sources in the YPD medium, the number of viable cells and the dry cell weight of $S$. boulardii both increased, which was significantly higher than that of the control group. Different inorganic nitrogen sources had various effects on cell growth. The order of utilization rate was: urea $>$ diammonium hydrogen citrate $>$ triammonium citrate $>$ ammonium sulfate $>$ ammonium nitrate $>$ ammonium chloride $>$ potassium nitrate. The above results exhibited that the addition of urea had a significant promoting effect during the growth of $S$. boulardii. Therefore, urea was selected as the inorganic nitrogen source for the next test.

As can be seen from Figure 6, the number of viable cells and the dry cell weight both increased first and then decreased with the increase of urea concentration.

When the urea concentration was $0.4 \%$, the number of viable cells reached the maximum value of $1.66 \times 10^{8} \mathrm{CFU} / \mathrm{mL}$, the dry cell weight was $3.6922 \mathrm{~g} / \mathrm{L}$; furthermore, the $\mathrm{pH}$ value of the culture solution did not change significantly with the increase of urea concentration. According to the above results, $0.4 \%$ of urea was beneficial to the cell growth.

Effect of prebiotics on the growth of Saccharomyces boulardii

$0.5 \%$ xylo-oligosaccharide (XOS), isomaltooligosaccharide (IMO), fructo-oligosaccharide (FOS), galacto-oligosaccharide (GOS), stachyose, raffinose, and inulin were added to YPD medium. The effects of various prebiotics on the growth of $S$. boulardii were compared with YPD medium as control group (Figure 7). With the exception of inulin, the number of viable cells and the dry cell weight of the other test group cultures were greater than those of the control group, indicating that they were beneficial to the growth of $S$. boulardii. Among them, FOS and GOS had the most obvious growth-promoting effect on the $S$. boulardii. The viable counts of the FOS group and the GOS group were $2.09 \times 10^{8} \mathrm{CFU} / \mathrm{mL}$ and $2.11 \times 10^{8} \mathrm{CFU} / \mathrm{mL}$, respectively. It was about $40 \%$ higher than that of the control group $\left(1.43 \times 10^{8} \mathrm{CFU} / \mathrm{mL}\right)$; the dry cell weight was $3.5102 \mathrm{~g} / \mathrm{L}$ and $3.6978 \mathrm{~g} / \mathrm{L}$, respectively, which was $29.5 \%$ and $36.2 \%$ higher than that of the control group $(2.7178 \mathrm{~g} / \mathrm{L})$. Therefore, FOS and GOS were selected for further testing.

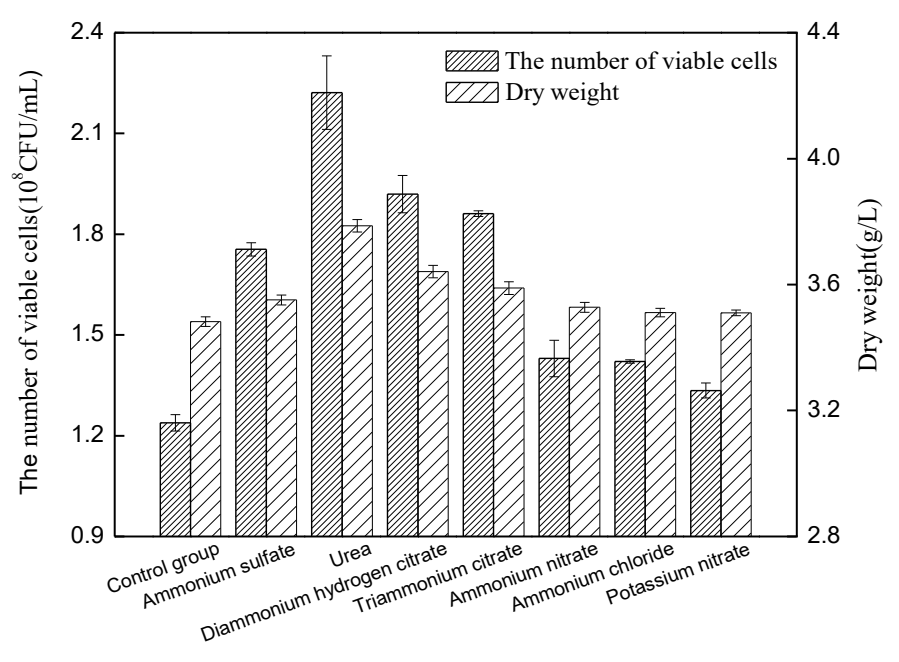

Figure 5. Effect of inorganic nitrogen sources on the growth of $S$. boulardii

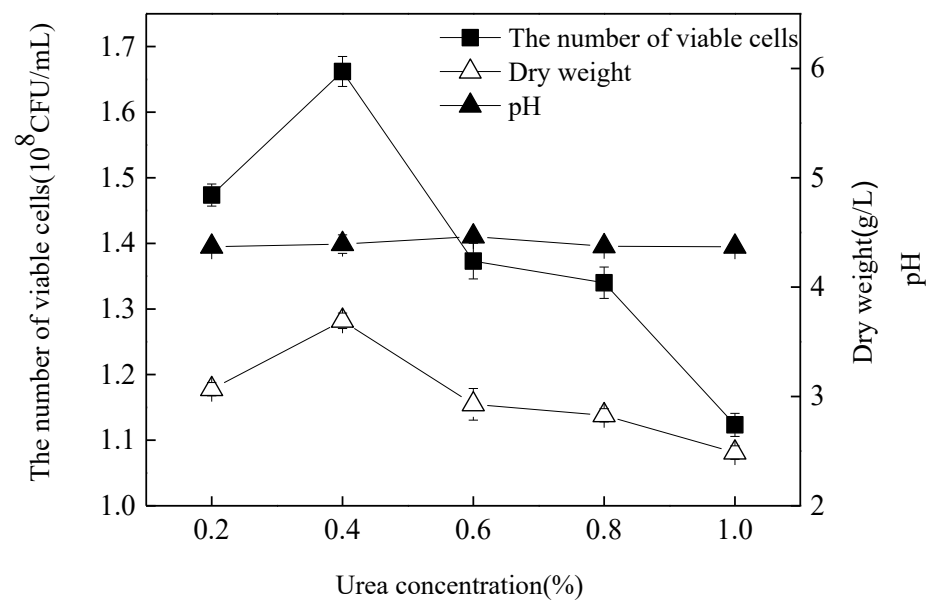

Figure 6. Effect of urea on the growth of $S$. boulardii

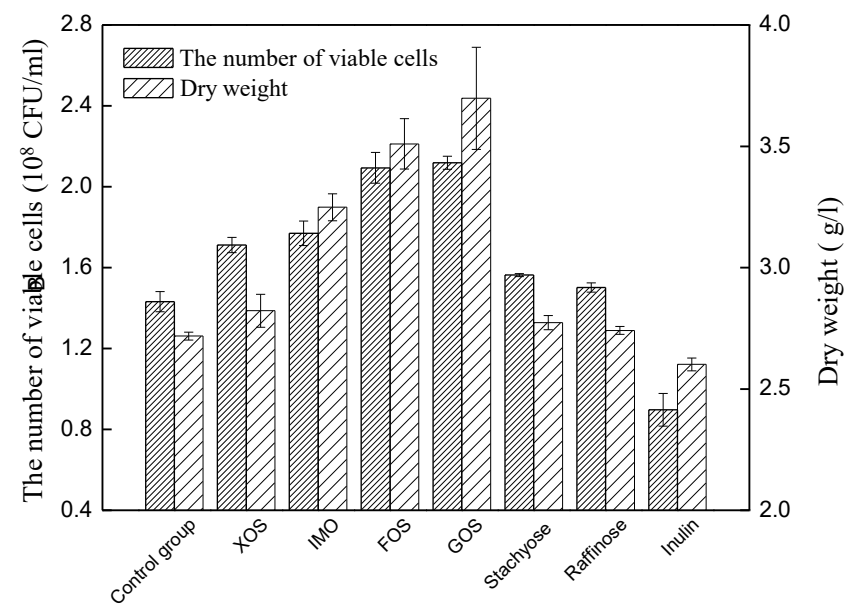

Figure 7. Effect of prebiotics on the growth of $S$. boulardii 
According to Figure 8(a), the number of viable cells and the dry cell weight decreased as the the concentration of FOS increased. When the concentration of FOS was $0.2 \%$, the number of viable cells was $1.89 \times 10^{8} \mathrm{CFU} / \mathrm{mL}$ and the dry cell weight was $3.2656 \mathrm{~g} / \mathrm{L}$, respectively. In Figure $8(\mathrm{~b})$, both the number of viable cells and the dry cell weight increased first and then decreased with the increase of the amount of GOS, and reachd a maximum value of $2.13 \times 10^{8} \mathrm{CFU} / \mathrm{mL}$ and 3.9521 $\mathrm{g} / \mathrm{L}$ at a concentration of $0.6 \%$. In addition, the $\mathrm{pH}$ in the culture solution decreased as the concentration of FOS and GOS increased, but the decrease was small. From the above results, it was found that $0.2 \%$ of FOS and $0.6 \%$ of GOS can significantly promote cell growth.

Prebiotics are a dietary supplement that stimulates the growth of probiotics, exerts physiological functions through probiotics, regulates the intestinal flora of the body, and produces beneficial substances. Cheng et al. found that the optimum concentration of inulin $(0.7 \%)$, isomaltooligosaccharide $(0.5 \%), \mathrm{Na}_{2} \mathrm{HPO}_{4}(0.4 \%)$, $\mathrm{CH}_{3} \mathrm{COONa}(0.4 \%)$, leucine $(20 \mathrm{mg} / \mathrm{L})$, serine $(20$ $\mathrm{mg} / \mathrm{L}$ ) for Lactobacillus plantarum LP69 was estimated with the activity of cell-envelope proteinase (CEP) in the range 17.36-21.47 U/mL, protein content in the range $19.18-22.53 \mathrm{mg} / \mathrm{mL}$, specific activity in the range $0.77-1.12 \mathrm{U} / \mathrm{mg}$. Inulin, isomaltooligosaccharide, $\mathrm{Na}_{2} \mathrm{HPO}_{4}$, $\mathrm{CH}_{3} \mathrm{COONa}$, leucine and serine are superior to other selected substances, and have a significant influence on the CEP activity and specific activity of Lactobacillus plantarum LP69 (Cheng et al., 2019).

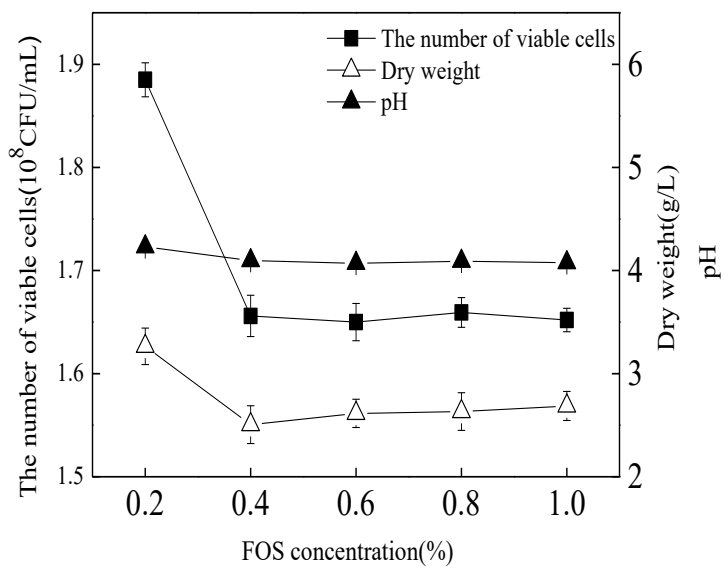

(a)

Figure 8. Effect of the concentration of fructo-oligosaccharides

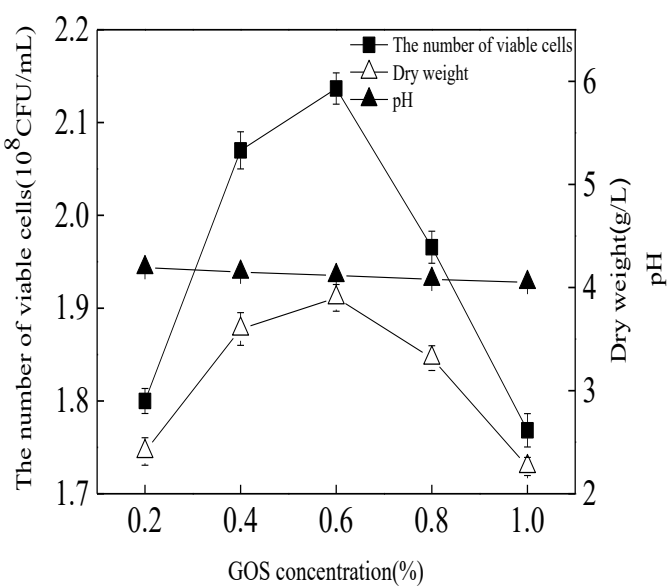

(b)

boulardii

\section{CONCLUSIONS}

In this experiment, the effects of carbon sources, nitrogen sources, and prebiotics on the growth of $S$. boulardii were investigated by single factor analysis. The result showed that glucose, sucrose, peptone, yeast extract, fructo-oligosaccharide, and galacto-oligosaccharide had a significant influence. Glucose and sucrose were the optimum carbon sources compared to other carbon sources, with an optimal concentration of $5 \%$ for glucose and sucrose. When the nitrogen source was $2 \%$ yeast extract, $2 \%$ peptone, $0.4 \%$ urea, respectively, the growth of $S$. boulardii was significantly promoted. Furthermore, the addition of prebiotics also played an important role in the growth of $S$. boulardii, particularly fructooligosaccharide and galacto-oligosaccharide, with optimal concentration was $0.2 \%$ and $0.6 \%$, respectively.

\section{ACKNOWLEDGEMENTS}

The work was partially supported by the Key Research and Development Program of Shaanxi (Program No. 2019ZDLNY06-03). 


\section{REFERENCES}

1. Akil, I., Yilmaz, O., Kurutepe, S., Deqerli, K., Kavukcu, S. (2006). Influence of oral intake of Saccharomyces boulardii on Escherichia coli in enteric flora. Pediatric nephrology, 21(6), 807-810. http://dx.doi.org/10.1007/s00467-006-0088-4

2. Anvari, M., Khayati, G., Rostami, S. (2013). Optimisation of medium composition for probiotic biomass production using response surface methodology. Journal of Dairy Research, 81(01), 59-64. http://dx.doi.org/10.1017/s0022029913000733

3. Buts, J. P., Dekeyser, N., Stilmant, C., Delem, E., Smets, F., Sokal, E. (2006). Saccharomyces boulardii produces in rat small intestine a novel protein phosphatase that inhibits Escherichia coil endotoxin by $\begin{array}{llll}\text { dephosphorylation. } & \text { Pediatric } & \text { Research, }\end{array}$ http://dx.doi.org/10.1203/01.pdr.0000220322.31940.29

4. Cheng, Fangfang., Chen, He., Lei, Ni., Zhang, Meng., Wan, Hongchang., Shu, Guowei. (2019). Effect of prebiotics, inorganic salts and amino acids for cell envelope proteinase production from Lactobacillus plantarum LP69. Acta scientiarum polonorum. Technologia alimentaria, 18(3). http://dx.doi.org/10.17306/J.AFS.0656

5. Corona-Hernandez, R. I., Álvarez-Parrilla, E., Lizardi-Mendoza, J., Islas-Rubio, A. R., de la Rosa, L. A., Wall-Medrano, A. (2013). Structural Stability and Viability of Microencapsulated Probiotic Bacteria: A Review. Comprehensive Reviews in Food Science and Food Safety, 12(6), 614-628. http://dx.doi.org/10.1111/1541-4337.12030

6. Czerucka, D., Piche, T., Rampal, P. (2010). Review article: yeast as probiotics -- Saccharomyces boulardii. Alimentary Pharmacology \& Therapeutics, 26(6), 767-778. http://dx.doi.org/10.1111/j.13652036.2007.03442.x

7. Edwards-Ingram, L., Gitsham, P., Burton, N., Warhurst, G., Clarke, I., Hoyle, D., Oliver, S. G., Stateva, L. (2007). Genotypic and physiological characterization of Saccharomyces boulardii, the proboscis strain of Saccharomyces cerevisiae. Applied and Environmental Microbiology, 73(8), 2458-2467. http://dx.doi.org/10.1128/AEM.02201-06

8. Elmer, G. W., Mcfarland, L. V., Surawicz, C. M., Danko, L., Greenberg, R. N. (2000). Behaviour of saccharomyces boulardii in recurrent clostridium difficile disease patients. Alimentary Pharmacology \& Therapeutics, 13(12), 1663-1668. http://dx.doi.org/10.1046/j.1365-2036.1999.00666.x

9. Fietto, J. L., Araújo, R. S., Valadão, F. N., Fietto, L. G., Brandão, R. L., Neves, M. J., Gomes, F. C., Nicoli, J. R., Castro, I. M. (2004). Molecular and physiological comparisons between Saccharomyces cerevisiae and Saccharomyces boulardii. Canadian Journal of Microbiology, 50(8), 615- 621. http://dx.doi.org/10.1139/w04-050

10. George Kerry, R., Patra, J. K., Gouda, S., Park, Y., Shin, H.-S., Das, G. (2018). Benefaction of probiotics for human health: A review. Journal of Food and Drug Analysis, 26(3), 927-939. http://dx.doi.org/10.1016/j.jfda.2018.01.002

11. Ghasem, B., Hosnie, G., Bahare, Z., Najmeh, Z., Farzin, R., Ardakani, E.M., Azizi, M., Khalaj, V. (2018). Oral administration of recombinant Saccharomyces boulardii expressing ovalbumin-cpe fusion protein induces antibody response in mice. Frontiers in Microbiology, 9, 723 -. http://dx.doi.org/10.3389/fmicb.2018.00723

12. Kailasapathy, K. (2015). Encapsulation and controlled release techniques for administration and delivery of bioactive components in the health food sector. Nutraceutical and Functional Food Processing Technology, John Wiley \& Sons, Ltd.

13. Malgoire, J. Y., Bertout, S., Renaud, F., Bastide, J. M., Mallié, M. (2005). Typing of Saccharomyces cerevisiae clinical strains by using microsatellite sequence polymorphism, Journal of Clinical Microbiology, 43(3), 1133-1137. http://dx.doi.org/10.1128/JCM.43.3.1133-1137.2005

14. Mansour-Ghanaei, F., Dehbashi, N., Yazdanparast, K., Shafaghi, A. (2003). Efficacy of Saccharomyces boulardii with antibiotics in acute amoebiasis. World Journal of Gastroenterology, 9(8), 1832-1833. http://dx.doi.org/10.3748/wjg.v9.i8.1832

15. McFarland, L. V. (2006). Meta-analysis of probiotics for the prevention of antibiotic associated diarrhea and the treatment of Clostridium difficile disease. American Journal of Gastroenterology, 101(4), 812-822. http://dx.doi.org/10.1111/j.1572-0241.2006.00465.x 
16. McFarland, L. V. (2010). Systematic review and meta-analysis of Saccharomyces boulardii in adult $\begin{array}{lllll}\text { patients. World Journal of } & \text { 2202-2222. }\end{array}$ http://dx.doi.org/10.3748/wjg.v16.i18.2202

17. McGroarty, J. (1993). Probiotics use of lactobacilli in the human female urogenital tract. FEMS Immunology and Medical Microbiology, 6(4), 251-264. http://dx.doi.org/10.1111/j.1574695X.1993.tb00337.x

18. Perdigon, G., Alvarez, S., Rachid, M., Agüero, G., Gobbato, N. (1995). Immune system stimulation by probiotics. Journal of Dairy Science, 78 (7), 1597-1606. http://dx.doi.org/10.3168/jds.S00220302(95)76784-4

19. Prabhu, A. A., Mandal, B., Dasu, V. V. (2017). Medium optimization for high yield production of extracellular human interferon- $\gamma$ from Pichia pastoris: A statistical optimization and neural networkbased approach. Korean Journal of Chemical Engineering, 34(4), 1109-1121. http://dx.doi.org/10.1007/s11814-016-0358-1

20. Szajewska, H., Mrukowicz, J. (2005). Meta-analysis: non-pathogenic yeast Saccharomyces boulardii in the prevention of antibiotic-associated diarrhoea. Alimentary Pharmacology and Therapeutics, 22(5), 365-372. http://dx.doi.org/10.1111/j.1365-2036.2005.02624.x

21. Szajewska, H., Skorka, A., Dylag, M. (2007). Meta-analysis: Saccharomyces boulardii for treating acute diarrhoea in children. Alimentary Pharmacology and Therapeutics, 25(3), 257-264. http://dx.doi.org/10.1111/j.1365-2036.2006.03202.x

22. Vanhee, L. M. E., Goemé F., Nelis, H. J., Coenye, T. (2010). Quality control of fifteen probiotic products containing Saccharomyces boulardii. Journal of Applied Microbiology, 109(5). 